\title{
PENGUATAN LITERASI MELALUI PROGRAM REVITALISASI SASTRA DAERAH DI NEGERI WARAKA KECAMATAN TELUK ELPAPUTH KABUPATEN MALUKU TENGAH
}

\author{
Elsa Latupeirissa, Yessa Gracia Monaten \\ Pendidikan Bahasa dan Sastra Indonesia, FKIP Universitas Pattimura, elsalatupeirissa@yahoo.co,id
}

\begin{abstract}
Abstrak: Kegiatan pengabdian Kepada Masyarakat yang bertempat di Negeri Waraka merupakan salah satu upaya dalam menghidupkan kembali sastra daerah yang hampir terlupakan oleh masyarakat setempat. Kegiatan pengabdian ini memberikan penguatan bagi masyarakat khususnya kaum pemuda dalam menjaga dan mempertahankan nilai-nilai budaya yang tercermin dalam karya-karya sastra berbasis lokal (daerah), mengingat kaum generesi muda adalah bagian yang penting namun juga bagian yang rentan dalam pemertahanan sastra itu sendiri. Penguatan literasi Sastra daerah merupakan bagian dalam memberdayakan masyarakat khususnya generasi muda di Negeri Waraka dalam mencintai karya sastra, sehingga tetap hidup dan berakar dalam tatanan kehidupan masyarakat setempat. Tujuan dari kegiatan Pengabdian Masyarakat ini adalah memberikan pemahaman tentang konsep sastra daerah serta memberikan penguatan bagi generasi muda untuk mempertahankan dan melestarikan sastra daerah sebagai bagian dari pewarisan budaya leluhur. Penyampaian tujuan ini dilakukan melalui metode ceramah, dan diskusi bersama untuk memperoleh gambaran tentang kehadiran sastra daerah dalam masyarakat khususnya di kalangan pemuda, sehingga dapat membuat program untuk menghidupkan kembali sastra daerah. Hasil dari kegiatan ini mampu meningkatkan kesadaran dan motivasi kaum pemuda untuk mencintai karya-karya sastra lokal (daerah) dan berupaya untuk mepertahankan serta melestarikannya.
\end{abstract}

Kata Kunci: Penguatan Literasi, Revitalisasi Sastra Daerah

\begin{abstract}
Community service activity which taking place in Negeri Waraka is an effort to restore regional literature that is almost forgotten by the local community. This Community Service activity provides reinforcement for the community, especially young people, in maintaining and preserving cultural values that are reflected in local-based (regional) literary works, bearing in mind that young generation is an important part but also a vulnerable part in the preservation of literature itself. Strengthening regional literacy is a part in empowering the community, especially the young generation in Negeri Waraka in loving literary works, so that it stays alive and rooted in the order of life of the local community. The purpose of this Community Service activity is to provide an understanding of the concept of regional literature and provide reinforcement for young people to maintain and preserve regional literature as part of the cultural heritage of ancestors. Submission of this goal is done through the lecture method, and joint discussion to obtain an overview of the presence of regional literature in society, especially among young people, so that they can create programs to restore regional literature. The results of this activity can increase the awareness and motivation of young people to love local (regional) literary works and strive to maintain and preserve them.
\end{abstract}

Keywords: Literacy strengthening, Regional Literature Revitalization

\section{PENDAHULUAN}

Globalisasi telah merasuk peradaban bangsa, walaupun ada sisi positifnya, namun tak dapat dipungkiri bahwa sisi negatif dari arus globalisasi ini juga menjadi ancaman perkembangan bangsa yang didalamnya juga ada budaya-budaya nasional dan budaya lokal yang pada akhirnya berdampak pada perubahan karakter pemilik budaya itu sendiri. Karakter generasi muda yang menjadi bagian dari pemilik budaya itu juga hampir diragukan seiring dengan pesatnya arus globalisasi bahkan kecenderungan dalam menyikapi persoalan hidup dengan berbagai pendekatan pun mulai dipengaruhi oleh arus globalisasi, oleh sebab itu penguatan terhadap karakter sebagai wujud jati diri bangsa perlu 
diformulasikan dan dikuatkan demi terciptanya generasi cerdas dan berbudi luhur. Penguatan karakter menjadi bagian penting dalam membangun sebuah peradaban.

Peradaban dan kebudayaan itu sendiri tidak bisa dilepaspisahkan dari kehidupan manusia, peradaban merupakan bagian dari kebudayaan yang bertujuan untuk memudahkan dan mensejahterakan kehidupan manusia. Kebudayaan akan memberikan arah bagi seseorang dalam bertindak dan berpikir yang pada akhirnya akan melahirkan ide-ide serta nilai untuk menjalani hidup yang layak. Cakupan kebudayaan sangatlah luas dan kompleks, yang semuanya menyentuh pada sendi-sendi kehidupan manusia, termasuk di dalamnya karya-karya sastra yang merupakan bagian dari hasil cipta masyarakat..

Keberadaan sastra di masyarakat menunjukkan seberapa besar tingkat respon masyarakat terhadap fenomena kebudayaan yang ada di daerahnya. Sastra hadir sebagai bagian dari cara pandang masyarakat pendukung dalam memberikan nilai terhadap karyanya. Nilai itu memberikan dampak bagi kolektif yang dijadikan sebagai tolok ukur dalam hidup bermasyarakat. Dalam dunia sastra, kita mengenal adanya sastra dunia, sastra Nasional, dan sastra Daerah atau Sastra Lokal, yang masingmasing menghadirkan karya-karya yang telah diakui keberadaannya. Persoalannya adalah apakah karya-karya itu mampu bertahan dalam era globalisasi ini dan apakah ada upaya untuk mempertahankan karya itu?. Hal inilah yang menjadi dasar pikir dilakukannya kegiatan Pengabdian Kepada Masyarakat (selanjutnya disingkat PKM) ini sebagai bagian dari Tri Dharma Perguruan Tinggi.

Upaya yang dilakukan dalam kegiatan PKM ini merujuk pada kegiatan untuk menghidupkan kembali atau merevitalisasi karya-karya sastra yang hampir dilupakan oleh masyarakat khususnya oleh kaum pemuda. Akhir-akhir ini kita sering mendengar istilah revitalisasi yang semakin giat dilakukan oleh pihak-pihak atau komunitas tertentu dalam wacana publik. Revitalisasi dipergunakan dalam berbagai konteks, misalnya Revitalisasi Monas yang beberapa waktu lalu menjadi perhatian publik khusus untuk masyarakat Jakarta, atau revitalisasi aset yang dilakukan oleh pemerintah kota Bandung untuk mengoptimalkan aset Negara, atau juga revitalisasi sastra yang bertujuan untuk menghidupkan kembali sastra untuk diberdayakan. Jadi istilah revitalisasi ini mencakup semua aspek kehidupan manusia.

Revitalisasi itu sendiri adalah suatu proses atau upaya untuk menghidupkan atau menggiatkan kembali sesuatu hal. Terkait dengan Kegiatan PKM yang dilakukan sebenarnya merupakan suatu keprihatinan terhadap generasi muda yang mengabaikan sastra daerah (lokal), padahal sastra daerah (lokal) itu masih ada di tengah-tengah masyarakat namun tidak diberdayakan dengan baik. Ketidakpeduliaan inilah yang lambat laun akan mematikan karya-karya sastra daerah yang semestinya memberikan penguatan bagi mereka dalam melangsungkan kehidupan bersama.

Kegiatan PKM ini sebenarnya merupakan langkah awal untuk memicu dan memacu generasi muda dalam menyikapi persoalan ketidakpedulian generasi muda terhadap warisan budaya leluhur. Kegiatan PKM bertujuan untuk memberikan pemahaman tentang konsep sastra daerah serta memberikan motivasi bagi generasi muda sebagai pilar utama dalam menjaga dan melestarikan budaya daerah termasuk di dalamnya karya-karya sastra. Menghidupkan kembali sastra daerah dan memberdayakannya sesuai konteks dalam kehidupan bermasyarakat.

Berdasarkan tujuan kegiatan PKM ini maka rencana pemecahan masalah yang dilakukan adalah membuat kegiatan literasi sebagai bentuk penguatan bagi generasi muda untuk memotivasi mereka dalam mempertahankan dan melestarikan sastra daerah. Kegiatan ini dimulai dengan memberikan sosialisasi tentang konsep sastra daerah serta menunjukkan bahwa betapa pentingnya menghidupkan dan memberdayakannya untuk kehidupan bersama. Selanjutnya menginventarisasi karya-karya sastra yang berbasis lokal (daerah) dan mengubungkannya dengan berbagai aspek kehidupan masyarakat setempat.

Zaidan mengemukakan bahwa sastra daerah adalah gendre sastra yang ditulis dalam bahasa daerah dan bertema universal (Didipu, $2010: 1$ ). Sastra daerah memiliki kedudukan yang sangat penting di tengah-tengah masyarakat, dikarenakan sastra daerah dapat menjadi wahana pembelajaran untuk memahami masyarakat dan budayanya. Sangatlah jelas terlihat bahwa sastra tidak akan pernah dilepaspisahkan dari konteks kebudayaan. Selanjutnya Tuloli menyatakan bahwa sastra daerah mempunyai kedudukan sebagai berikut: 1) sastra daerah adalah ciptaan masyarakat masa lampau atau mendahului penciptaan sastra Indonesia Modern; 2) sastra daerah dapat dimasukan dalam salah satu aspek budaya Indonesia yang perlu digali untuk memperkaya budaya nasional; 3) sastra daerah melekat pada jiwa, rohani, kepercayaan dan adat istiadat masyarakat suatu bangsa dan yang mereka pakai untuk menyampaikan nillai-nilai luhur bagi generasi muda; 4). sastra daerah mempunyai kedudukan yang 
strategis dan kerangka spembangunan sumber daya manusia, yaitu untuk memperkuat kepribadian keindonesiaa yang berbhineka tunggal ika.

Berdasarkan bentuknya, sastra daerah dibagi atas dua yaitu sastra daerah tulis dan sastra daerah lisan. Sastra daerah tertulis hadir dalam bentuk naskah-naskah tua dan sering dikaji secara filologi. Sementara sastra daerah lisan atau sastra lisan merupakan karya sastra yang penyebarannya melalui mulut ke mulut secara turun temurun (Endraswara, 2008:151). Sastra daerah akan tetap hidup bila didukung oleh pemiliknya, sebaliknya akan punah bila pemiliknya tidak lagi mempedulikan keberadaannya apalagi sastra daerah lisan yang proses pewarisannya dari mulut ke mulut akan lebih cepat meredup bila diabaikan. Bila fenomena ini terjadi maka perlu ada upaya untuk memberdayakan kembali sehingga sastra itu tetap ada dan tetap dipakai dalam konteks-konteks tertentu.

Revitalisasi sastra adalah sebuah upaya atau cara untuk mempertahankan sastra suapaya tetap hidup. Berbagai cara yang ditempuh unuk menggiatkan kembali sastra dan menjadikannya sebagai bagian yang penting dalam masyarakat pendukungnya. Salah satu tujuan merevitalisasi sastra adalah untuk menghidupkan kembali pendidikan karakter, karena karakter atau kepribadian sering diperkenalkan lewat karya-karya sastra. Karya sastra yang bersifat lokal atau daerah akan menghidupkan karakter masyarakat lokal itu sendiri. Hal ini sangatlah penting karena karakter atau identitas lokal akan menunjukkan warna lokal yang berbeda dari daerah yang lain.

Revitalisasi sastra perlu diupayakan dengan berbagai cara salah satunya adalah dengan memberikan penguatan lewat gerakan literasi. Menghidupkan kembali budaya-budaya lokal dan tradisitradisi lokal sebagai gerakan membangun literasi masyarakat. Istilah literasi pada beberapa tahun terakhir ini juga banyak menyita perhatian publik, dalam berbagai ranah istilah ini dihubung-hubungkan bahkan diwujudkan dalam beberapa kegiatan nyata. Yang paling sering kita dengar dan kerapkali ditindaklanjuti adalah pada ranah pendidikan. Bukan saja pendidkan secara formal, namun pendidikan nonformal dalam masyarakat pun sudah diimplementasikan. Literasi bukan hanya sekadar membaca, menulis, dan berhitung, tetapi memiliki pengertian yang lebih luas dan kompleks yaitu segenap potensi dan keterampilan yang dimiliki seseorang dalam hidupnya.

Dalam bahasa Latin, istilah literasi disebut sebagai literatus, artinya adalah orang yang belajar. Selanjutnya, National Institut for Literacy menjelaskan bahwa yang dimaksud dengan literasi adalah kemampuan seseorang untuk membaca, menulis, berbicara, menghitung dan memecahkan masalah pada tingkat keahlian yang diperlukan dalam pekerjaan, keluarga dan masyarakat. Education Development Center (EDC) juga turut menjabarkan pengertian dari literasi, yakni kemampuan individu menggunakan potensi yang dimilikinya, dan tidak sebatas kemampuan baca tulis saja. UNESCO juga menjelaskan bahwa literasi adalah seperangkat keterampilan yang nyata, khususnya keterampilan kognitif dalam membaca dan menulis yang terlepas dari konteks di mana keterampilan yang dimaksud diperoleh, dari siapa keterampilan tersebut diperoleh dan bagaimana cara memperolehnya (https://id.wikipedia.org/wiki/Literasi). Dengan demikian titik penting yang dilakukan dalam kegiatan PKM ini adalah upaya untuk memecahkan persoalaan ketidakpedulian generasi muda dalam menghadirkan sastra sebagai bagian yang vital dalam hidupnya.

\section{METODE PELAKSANAAN PENGABDIAN}

Metode yang dilkakukan pada kegiatan PKM ini adalah dalam bentuk sosialisasi tentang konsep sastra daerah dan penguatannya sebagai bagian dalam mempertahankan karya sastra daerah. Sosialisasi yang dilakukan terkait dengan judul kegiatan PKM ini dimulai dengan kegiatan survei awal dalam bentuk wawancara dengan beberapa stakeholder. Dari hasil wawancara dapat diidentifikasikan bahwa keberadaan sastra daerah hampir dilupakan oleh masyarakat khususnya generasi muda, karena pengaruh arus globalisasi sehingga hal-hal sederahana dan tradisional tidak lagi menjadi bagian dalam kehidupan mereka. Teknik ceramah dan diskusi ini dipilih untuk memberikan konsep tentang sastra daerah dan bagaimana upaya untuk menyelamatkannya dari kepunahan. Kegiatan PKM ini bertempat di Negeri Waraka Kabupaten Maluku Tengah pada tanggal 18 Januari 2020, dengan sasaran pelaksanaan adalah kepada kaum pemuda dengan pertimbangan bahwa kaum pemuda merupakan kader masyarakat yang selalu diidentikan dengan perubahan, menjadi penggerak dalam kehidupan masyarakat. Sebagai agen perubahan, pemuda selalu memiliki kekuatan untuk mempengaruhi pola pikir dalam masyarakat, sehingga sasaran ini ditujukan kepada kalangan pemuda. Di samping kegiatan ceramah dan diskusi, juga dilakukan teknik-teknik pengumpulan data lainnya yakni wawancara dengan beberapa tokoh masyarakat sebagai bagian dalam mencocokan dan menghubungkan informasi yang 
diterima melalui kegiatan diskusi dengan kalangan pemuda. Informasi (data) yang didapatkan melalui diskusi dan wawancara tersebut menjadi langkah awal untuk menentukan langkah selanjutnya yaitu menginventarisasi sastra daerah yang ada untuk dijadikan sebagai referensi tertulis yang akan digunakan pada masyarakat setempat.

\section{PEMBAHASAN}

Kegiatan PKM yang dilakukan di Negeri Waraka Kabupaten Maluku Tengah memberikan sebuah catatan penting tentang bagaimana proses pewarisan karya-karya sastra itu berlangsung. Negeri Waraka merupakan salah satu negeri adat di Maluku yang selalu mengutamakan hukum adat dalam semua aspek kehidupan. Yang paling unik dari negeri ini adalah sistem pemerintahan negeri yang dikepalai oleh seorang Raja dan dalam proses penentuan raja tidak seperti proses pemilihan raja pada daerah-daerah lain pada umumnya.

Pendekatan dalam penentuan raja (pimpinan negeri) di negeri Waraka ini telah diatur sejak dahulu kala, dan telah menjadi konvensi bersama sehingga harus tunduk pada konvensi itu. Konvensi ini menjadi aturan yang baku yang tidak bisa diganggu gugat oleh siapapun. Mata rumah parentah (turunan raja) memiliki kekuasaan dan hak-hak tertentu dalam menjalankan roda pemerintahan negeri. Hal ini menunjukan adanya budaya atau tradisi yang mengikat kehidupan masyarakat yang tidak bisa digugat keberadaannya. Adat yang mengikat kehidupan bersama menunjukkan sebuah identitas masyarakat yang akan selalu dihubungkan dengan budaya lokal yang tertanam dalam kehidupan masyarakat. Hal ini juga mempengaruhi proses pewarisan budaya yang di dalamnya juga ada karyakarya sastra daerah atau lokal.

Sastra daerah (lokal) yang hidup dalam masyarakat akan menunjukkan tingkat kepedulian masyarakat dan bagaimana proses pemertahannya atau pewarisannya. Sastra harus tetap hidup dalam masyarakat karena berhubungan dengan konsep pengetahuan dan pola pikir serta tingkah laku masyarakat. Berbagai upaya dilakukan untuk mempertahankan dan menghidupkan sastra daerah di tengah-tengah pesatnya arus globalisasi, salah satunya seperti yang dilakukan dalam kegiatan PKM ini adalah dengan memberikan penguatan literasi sebagai bentuk merevitalisasi sastra daerah.

Kegiatan ini memberikan penguatan kepada masyarakat khususnya kaum Pemuda tentang pentingnya mempertahankan warisan budaya leluhur yang terpotret dalam karya sastra berbasis lokal atau daerah, sebagai bagian dari suatu kearifan lokal yang akan memberi warna bagi kehidupan masyarakat. Budaya-budaya itu tercermin juga dalam karya-karya sastra yang hidup dalam masyarakat.

Kegatan literasi yang dilakukan merupakan penguatan dalam memperoleh sejumlah informasi mengenai pentingnya mempertahankan dan melestarikan sastra daerah. Di dalamnya ada kemampuan untuk menghubungkan sastra daerah dengan arus modernisasi sehingga sastra daerah akan tetap tumbuh bersama seiring kemajuan IPTEK. Penguatan literasi ini memberikan pemahaman terhadap ide-ide atau konsep untuk memberdayakan sastra daerah ini menjadi bagian yang sangat penting dalam kehidupan bersama. Kegiatan PKM yang merupakan bagian dari Tri Dharma Perguruan Tinggi, perlu melihat peluang ini sebagai kesempatan dalam menanggulangi problematik yang sementara terjadi di masyarakat, atau dengan kata lain kegiatan PKM ini sebagai upaya dalam mengoptimalkan program Literasi. Upaya yang dilakukan dalam kegiatan ini bertujuan untuk memberikan kesadaran kepada masyarakat khususnya kaum pemuda tentang pentingnya menanamkan budaya daerah mengingat hampir terlupakan sastra daerah sehingga cara ini ditempuh sebagai upaya untuk mengingat dan menghidupkan kembali.

Kegiatan PKM dengan judul Penguatan Literasi Melalui Program Revitalisasi Sastra Daerah pada Pemuda di Desa Waraka yang dilakukan dengan menyajikan beberapa materi: 1) Penguatan Gerakan Literasi Dalam Keluarga; 2) Mengubah Persepsi Generasi Muda dan Menghidupkan kembali sastra Daerah. Kedua topik ini dipilih dalam kegiatan sosialisasi ini sebagai proses penanaman konsep bagi generasi muda terkait dengan kegiatan revitalisasi sastra. Pendidikan formal dan nonformal merupakan bagian penting dalam menghidupkan sastra daerah, oleh sebab itu perlu upaya dari berbagai kalangan dalam melihat persoalan ini. Pendidikan nonformal dimulai dari kehidupan keluarga yang merupakan dasar pembelajaran. Keluarga merupakan dasar pembentukan mental dan tingkah laku manusia termasuk di dalamnya generasi muda. Melalui lingkungan keluarga, anak mengenal dunia sekitar. Melalui keluarga anak mengenal adat-sitiadat, budaya yang menjadi bagian dalam hidup bersama. Anak dapat berinteraksi dengan nyaman dalam lingkungan keluarga, sehingga proses pewarisan budaya dapat dengan mudah diserap dan diingat. Gerakan literasi merupakan kemampuan 
memahami informasi melalui kegiatan-kegiatan berbahasa. Bila dikaitkan dengan literasi sastra maka akan mengarah kepada kemampuan mendapatkan dan memahami informasi sastra dengan kegiatankegiatan berbahasa.

Pada umumnya masyarakat Indonesia dipengaruhi oleh budaya tutur sehingga proses pewarisannya pun dilakukan secara oral. Tradisi bercerita terjadi secara turun temurun dari orang tua kepada anak-cucunya, artinya cerita yang dikisahkan orang tua kepada anak-anaknya kelak juga akan diceritakan anak-anak ketika menjadi orang tua kepada anak-anaknya. Kebiasaan ini akan berlangsung sepanjang mereka masih menganggap kebiasaan ini adalah hal yang penting. Oleh sebab itu orang tua juga harus memiliki sejumlah pengetahuan tentang adat-sistiadat, budaya termasuk jenis-jenis sastra daerah yang masih hidup sehingga akan memberikan banyak cerita bagi anak-anak. Generasi muda merupakan generasi penerus pengganti orang tua yang menjadi tonggak estafet untuk mempertahankan budaya dan adat-istiadat termasuk karya-karya sastra yang hidup di masyarakat. Penguatan literasi harus lebih diarahkan pada generasi muda supaya sastra daerah itu tetap diberdayakan dalam berbagai bentuk dan situasi. Di tangan pemudalah maka keberlanjutan budaya dan adat istiadat berlangsung.

Dari hasil kegiatan ini ditemukan beberapa sastra daerah yang masih ada namun tidak dijadikan sebagai bagian yang vital dalam kehidupan bermasyarakat khususnya kaum pemuda. Hal yang paling mendasar dari suatu karya sastra daerah adalah ada tidaknya bahasa lokal atau bahasa darah itu sendiri, karena bahasa daerah merupakan bahan dasar dari karya sastra itu. Di negeri Waraka, bahasa daerah sendiri masih ada dan masih dipertahankan hanya saja tidak semua orang peduli dan konsisten dalam menggunakan bahasa itu terkait juga dengan proses pewarisannya. Gambaran ini dapat dijadikan sebagai asumsi bahwa sastra daerah juga masih menjadi bagian dalam kehidupan masyarakat namun ketidakpedulian masyarakat membuat seolah-olah sastra itu tidak terlalu penting dan hanya berguna bagi segelintir orang.

Dari hasil diskusi bersama diperoleh data bahwa masih ditemukan karya-karya sastra seperti nyanyian rakyat, ungkapan rakyat, prosa rakyat, namun hanya pada kalangan tertentu saja yang mau menikmatinya, tidak banyak yang peduli keberadaannya. Kondisi ini pula akan mempengaruhi pelestarian sastra daerah sebagai bagian dari kekayaan budaya nasional. Kalau tidak ada kepedulian untuk melestarikan sastra daerah ini maka lama-kelamaan kita akan kehilangan warisan budaya yang telah diberikan secara cuma-cuma oleh para leluhur.

Berbagai upaya yang harus dilakukan untuk mengembalikan kembali warisan ini adalah mengangkat kembali dan mengingatkan para pemilik sastra untuk lebih aktif dalam menghidupkan kembali bagian yang yang hampir punah. Proses untuk menghidupkan kembali harus dimulai dari diri pemilik budaya itu, membangkitkkan emosi mereka sebagai usaha sadar bahwa warisan budaya daerah ini akan menjadikan mereka berbeda dari daerah yang lain. Budaya daerah ini memiliki kearifan lokal yang akan memberikan karakter yang kuat bagi pemiliknya untuk hidup sebagai makhluk pribadi dan juga sebagai makhluk sosial.

Upaya yang dilakukan ini menambah pengetahuan bagi pemiliknya bahwa mereka memiliki sejumlah sastra daerah yang perlu dijaga dan diertahankan. Pengetahuan masyarakat khusus generasi muda selaku pewaris memahami berbagai jenis sastra daerah dan memberi apresiasi dari sastra daerah itu sendiri. Sehingga masyarakat tidak akan kekurangan bahan cerita untuk mengisahkannya kembali kepada anak-anak mapun untuk dipilih sendiri oleh anak-anak cerita mana yang mereka butuhkan, tentunya cerita yang baik dan bermanfaat bagi mereka. Pelestarian sastra daerah sebagai upaya dalam menumbuhkembangkan budi pekerti masyarakat terkhusus kaum pemuda akan ditindaklanjuti oleh berbagai pihak termasuk pemerintah setempat.

Dengan melestarikan sastra daerah maka kita sudah memberikan apresiasi terhadap ciptaan masa lampau yang akan memperkaya budaya nasional. Dengan menjadikan sastra daerah sebagai bagian vital dalam kehidupan bersama akan selalu melekat dalam jiwa, rohani, kepercayaan dan adat istiadat dalam menyampaikan nilai-nilai luhur bagi generasi selanjutnya.

\section{PENUTUP}

Adapun simpulan yang dapat diangkat dari kegiatan ini adalah perlunya mengaktifkan kegiatan-kegiatan seperti penguatan literasi kepada generasi muda terkait dengan revitalisasi sastra daerah, mengingat generasi muda merupakan pilar utama dalam pembangunan. Di tangan generasi mudalah maka budaya, adat istiadat termasuk di dalamnya karya-karya sastra yang diciptakan oleh para leluhur akan tetap dipertahankan dan dilestarikan. Generasi muda perlu diingatkan terus bahwa mereka 
memiliki warisan yang tak ternilai,yang dapat menguatkan jati diri mereka. Melalui warisan budaya yang tercermin lewat karya-karya sastra mengajarkan mereka bagaimana membangun kehidupan bersama di tengah-tengah arus globalisasi, cara mereka menyikapi persoalan hidup, cara mereka memangun komunikasi, semua dapat tercermin lewat karya sastra daerah.

Sastra daerah yang dimiliki oleh masyarakat Waraka menjadikan mereka berbeda dengan daerah-daerah lainnya, warna lokal yang mereka miliki menjadikan mereka menjadi negeri yang unik, bukan hanya dalam ranah pemerintahan, tetapi dalam ranah sosial yang tercermin dari perilaku bersama dalam membangun komunikasi dan interaksi juga dapat menunjukkan budaya dan adat istiadat yang mengikat. Merevitalisasi sastra berarti menyelamatkan sastra dari kepunahan. Merevitalisasi sastra daerah berarti juga memberi apresiasi terhadap sastra yang berbasis lokal atau daerah sebagai bagian yang tak terpisahkan dari kehidupan bersama.

\section{REFERENSI}

Didipu, Herman. 2010. Sastra Daerah: Konsep Dasar Penelitian dan Pengkajiannya. Gorontalo: UNG Endraswara, Suwardi.2008. Metodologi Penelitian Sastra. Yogyakarta: Gadjah Mada University

Taum, Yoseph Yapi. 2011. Studi Sastra Lisan: Sejarah, Teori, Metode, dan Pendekatan Disertai Contoh Penerapannya. Yogyakarta: Lamalera

Teeuw, A. 2003 Sastera dan Ilmu Sastera. Jakarta: Pustaka Jaya 